\title{
GROUNDWATER QUALITY IN THE SHALLOW AQUIFERS OF THE HADAUTI PLATEAU OF THE DISTRICT OF BARAN, RAJASTHAN, INDIA
}

\author{
Lokesh KUMAR ${ }^{1}$, Amitava RAKSHIT ${ }^{*}$
}

\section{Abstract}

With the rapid pace of agricultural development, industrialization and urbanization, the commonly observed geogenic contaminants in groundwater are fluoride and nitrate, whereas nitrate is the dominant anthropogenic contaminant in the south-eastern plains of Rajasthan, India. Samples obtained using a tube well and hand pump in November, 2012, demonstrate that $\mathrm{Na}-\mathrm{Cl}$ is the dominant salt in the groundwater, and the total salinity of the water is between 211-1056 mg L-1. Moreover, the observed sodium adsorption ratio (SAR) and residual sodium carbonate (RSC) values ranged between 0.87 to 26.22 meq $L-1$ and -12.5 to 30.5 meq L-1 respectively. The study further shows that $6 \%$ of the total samples contain high amounts of nitrate, and $49 \%$ contain fluoride. A water quality index (WQI) rating was carried out using nine parameters to quantify the overall groundwater quality status of the area.
Address

1 Department of Soil Science and Agricultural Chemistry, Institute of Agricultural Sciences, BHU, Varanasi, UP-221005, India

Corresponding author: amitavabhu@gmail.com

\section{Key words}

- Groundwater quality,

- shallow aquifers,

- physicochemical parameters.

\section{INTRODUCTION}

The lack of adequate water resources for future generations is not only a regional issue but also a global concern. The amount of India's groundwater is under threat due to a variety of natural and human influences (Gupta et al., 2006). During the past two decades, the water levels in several parts of the country have been falling rapidly due to an increase in extraction (Gleick, 1993). The number of wells drilled for the irrigation of both food and cash crops has rapidly and indiscriminately increased in the last few years. India's rapidly rising population and changing lifestyles have also increased the domestic need for water (Rao, 1997). The water requirements for industry also show an overall rise. Intense competition among users, i.e., the agriculture, industry, and domestic sectors, is driving the groundwater table lower. Moreover, the quality of groundwater is becoming severely affected because of the widespread pollution of the surface water, air and land (Ciaccia, 1972) and has become a major problem today (Berner and Berner, 1987) affecting 45 million people around the world. If not treated properly the solid, liquid, and gaseous waste generated results in the contamination of the environment; this also affects groundwater due to the hydraulic connectivity in the hydrological cycle (Bandy, 1984). Besides, the discharge of untreated wastewater through bores and leachate from industrial waste and municipal solid waste also contaminate groundwater, thereby reducing the quality of fresh water resources.

Nitrates, fluoride and heavy metals occur as minor constituents of groundwater in all categories of hydro-geological settings in India. The high concentration of these inorganic contaminants is presently becoming a concern in the rural and urban areas of Rajasthan, as is indicated in the annual reports of the Central Groundwater Board, Delhi (Groundwater Scenario of Rajasthan). The high concentration of nitrates in drinking and irrigation water is mainly attributed to 


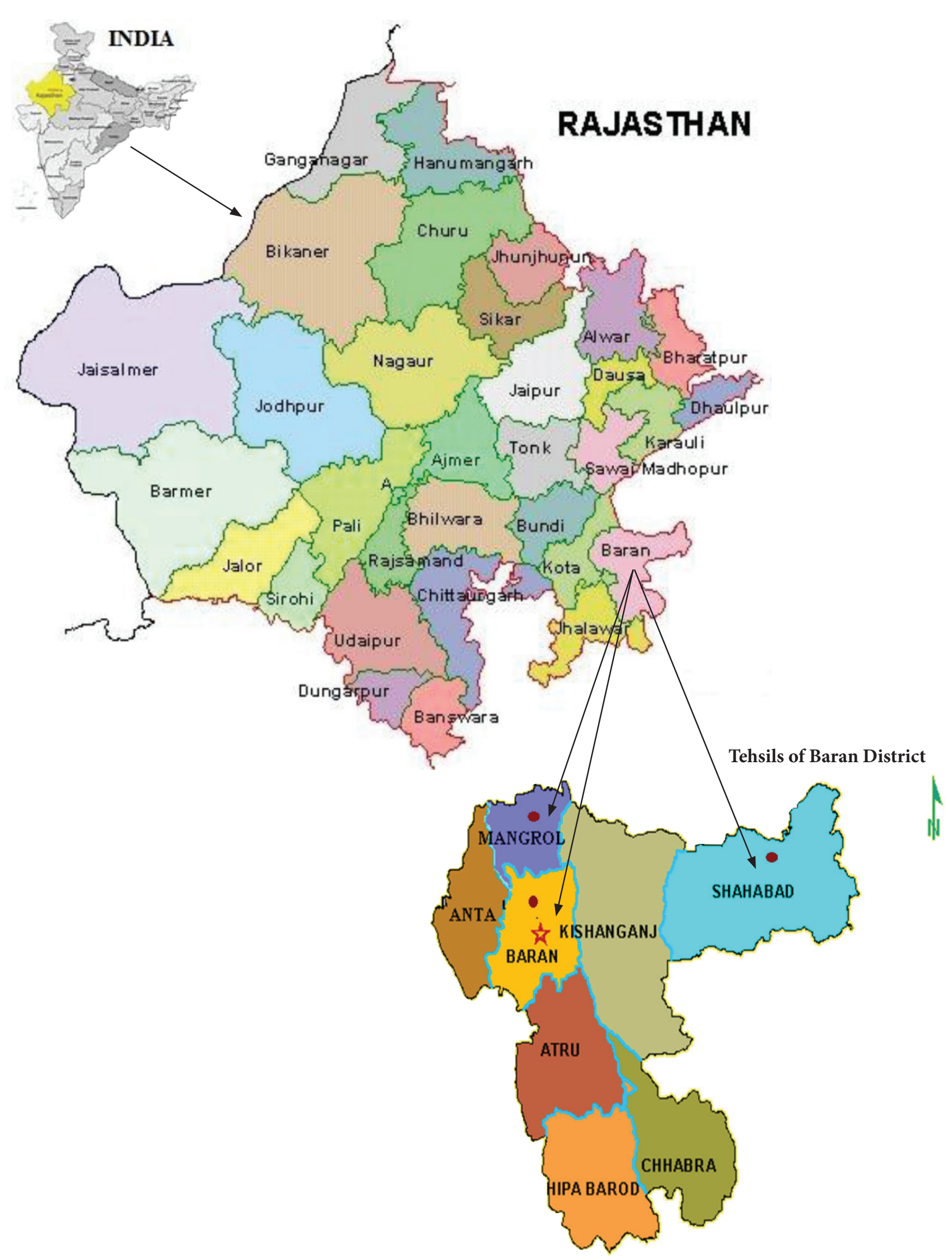

Fig. 1 Location of sampling site area on the south-eastern plain of the district of Baran, Rajasthan. 
anthropogenic activities. The use of nitrogenous fertilizer in 201112 was 1,488,938 million tons in Rajasthan (Groundwater Department, Jodhpur). The high concentration of nitrate in water beyond the permissible limit of $45 \mathrm{mg} \mathrm{L}^{-1}$ causes health problems such as methemoglobinaemia. From previous reports it is also evident that the groundwater is also contaminated with a high amount of fluoride, because the usual source of fluoride is fluoride-rich rock (Ozha, 2012). In Rajasthan the fluoride-rich rocks include fluorospar (CaF , sedimentary rocks, limestones and sandstones), cryolite (Na $\mathrm{AIF}^{2}$, igneous rocks, granite) and fluorapatite $\left(\mathrm{Ca}\left(\mathrm{PO}_{4}\right)(\mathrm{FClOH})\right){ }^{3}$ When water percolates through rocks, it leaches oưt the flutoride from these rocks (Ozha, 2012). As a result of the high concentration of fluoride in groundwater, cases of dental, skeletal and non-skeletal malformations are quite prevalent.

The quality of groundwater is of great importance in determining the suitability of a particular groundwater for a certain use. Information on the water quality of the humid southern-eastern plain of the district of Baran, Rajasthan, is scanty. Keeping these facts in mind, the present investigation was undertaken to evaluate the water quality parameters of the district of Baran for drinking and irrigation purposes.

\section{MATERIALS AND METHODS}

The area studied forms different parts of the district of Baran on the humid south-eastern plains of Rajasthan, commonly known as the Hadauti plateau. The district extends from the 24-25' to 25-25' North latitudes, 76-12' to 77-26' East longitudes, and 265 meters of altitude (Fig. 1). It covers a geographical area of $7994 \mathrm{~km}^{2}$. The average annual rainfall in the district of Baran is $895.2 \mathrm{~mm}$. January is the coldest month with an average daily maximum temperature of $24.3^{\circ} \mathrm{C}$ and an average daily minimum temperature of $10.6^{\circ} \mathrm{C}$; during the hot period, the annual temperature is 36.2 to $45.8^{\circ} \mathrm{C}$.

Sixty groundwater samples were collected from different tehsils (administrative subdivisions) in the district of Baran, Rajasthan, including Baran, Mangrol, Shahabad and Shahabad- Saheriyabasti during the post-monsoon season (November, 2012). One liter of groundwater samples was collected from different administrative subdivisions in the district of Baran. It was ensured that the concentration of different ions did not change in the time that elapsed between the drawing of samples for analysis in a laboratory. The water samples were collected in high-density plastic bottles and preserved by toluene in a laboratory for further analysis. All the samples were stored in sampling kits maintained at $4^{\circ} \mathrm{C}$.

The physico-chemical characteristics of the groundwater samples were determined using standard analytical methods (APHA, 1995). The $\mathrm{pH}$ was measured with digital $\mathrm{pH}$ meters. Their electric conductivity was measured with a conductivity bridge using a standard potassium chloride solution for the calibration and determination of the cell constant. The total degree of hardness and calcium plus magnesium was estimated by EDTA titrimetric methods. The total alkalinity, carbonate and bicarbonate were also estimated by titrimetric methods. The sodium and potassium were estimated by flame photometers, and the chloride ions were estimated by a standard $\mathrm{AgNO}_{3}$ titration. The fluoride and nitrate contents in the groundwater were determined electrochemically, using EDT direct ion selective electrode methods and the water quality index (WQI) was computed by a WQI calculator on the basis of the $\mathrm{pH}$, temperature, and nitrate parameters with their weighting factor.

The sodium hazard is typically expressed as the SAR. This index quantifies the proportion of sodium $\left(\mathrm{Na}^{+}\right)$to calcium $\left(\mathrm{Ca}^{2+}\right)$ and magnesium $\left(\mathrm{Mg}^{2+}\right)$ ions in a sample, which is expressed as

$$
S A R=\frac{\left[\mathrm{Na}^{+}\right]}{\sqrt{\frac{1}{2}\left(\left[\mathrm{Ca}^{2}\right]+\left[\mathrm{Mg}^{2+}\right]\right)}},
$$

where the residual sodium carbonate (RSC) equals the sum of the bicarbonate $\left(\mathrm{HCO}_{3}^{-}\right)$and carbonate $\left(\mathrm{CO}_{3}^{2-}\right)$ ion concentrations minus the sum of the calcium and magnesium ion concentrations expressed by $\mathrm{RSC}\left(\right.$ meq L $\left.{ }^{-1}\right)=\left(\mathrm{CO}_{3}^{2-}+\mathrm{HCO}_{3}^{-}\right)-\left(\mathrm{Ca}^{2+}+\mathrm{Mg}^{2+}\right)$.

\section{RESULTS AND DISCUSSION}

In general the groundwater quality in shallow aquifers is suitable for use for different purposes, except for a few areas in which a high concentration of some of the constituents are reported. The quality of the deeper aquifers varies from place to place, and exploration work is going on to assess the suitability of their water for various uses. A high incidence of constituents such as fluoride and nitrate has been reported from some of the areas, which has mostly been attributed to geogenic causes. Similarly salinity, both in the inland and coastal areas, has been reported from various parts of the country. Nitrate, fluoride and heavy metals are the important constituents, the high concentration of which poses severe health problems, which may be attributed to anthropogenic activities.

The predominant cations and anions in the groundwater are in the following order: $\mathrm{NO}_{3}>\mathrm{Na}^{+}>\mathrm{Ca}^{2+}+\mathrm{Mg}^{2+}>\mathrm{Cl}>\mathrm{HCO}_{3}>\mathrm{F}^{-}>\mathrm{CO}_{3}{ }^{2-}$ $>\mathrm{K}^{+}$, respectively during the sampling time, The samples are analyzed for the major cations, anions, physico-chemical parameters and water quality index for evaluating the groundwater's quality and its suitability for various uses (Table 1). An examination of the major ion concentration data reveals that $\mathrm{Na}^{+}$and $\mathrm{Cl}^{-}$are the major cations and anions respectively, irrespective of the nature of the source (Datta and Tyagi, 1996).

The Na concentration observed in the hand pump water ranged between 1.5 to $67.3 \mathrm{meq} \mathrm{L}^{-1}$ and between 4.2 to $14.8 \mathrm{meq} \mathrm{L}^{-1}$ in the tube well water. The calcium plus magnesium $\left(2.3-32.0 \mathrm{meqL}^{-1}\right)$, potassium $\left(0.01-0.70 \mathrm{meqL}^{-1}\right), \mathrm{CO}_{3}{ }^{2-}\left(0-1-1.1 \mathrm{meqL}^{-1}\right), \mathrm{HCO}_{3}^{-}(2.0$ - $\left.8.3 \mathrm{meq} \mathrm{L}^{-1}\right), \mathrm{Cl}^{-}\left(1.9-31.0 \mathrm{meq} \mathrm{L}^{-1}\right)$ values (Table 1$)$ of the water samples are well within the highest desirable or maximum permissible limits set by Food and Agriculture Organization (FAO), Bureau of Indian Standards (BIS) and World Health Organization (WHO).

Nitrate was found above the permissible limits $\left(>45 \mathrm{mg} \mathrm{L}^{-1}\right)$ in $6 \%$ of the samples. The observed $\mathrm{NO}_{3}^{-}$values in the tube well water ranged from 0.01 to $158.8 \mathrm{mg} \mathrm{L}^{-1}$, while the $\mathrm{NO}_{3}^{-}$values in the hand pump water ranged between 0.01 to $210.4 \mathrm{mg} \mathrm{L}^{-1}$ (Table 1). Nitrogenous materials are rare in the geological record; therefore, the occurrence of nitrate in groundwater is an anthropogenic pollutant contributed by nitrogenous fertilizers, industrial effluents, and human and animal waste through the biochemical activity of nitrifying bacteria, such as Nitrosomonas and Nitrobacter. All the sources of nitrogen are potential sources of nitrate. In water, especially groundwater, these sources include decaying plant or animal material, agricultural fertilizers, manure, domestic sewage, industrial wastewater, precipitation, or geological formations containing soluble nitrogen compounds. The nitrate concentration in groundwater was generally low for all the samples except for $6 \%$ of the samples, which were higher than the permissible limits $\left(>45 \mathrm{mg} \mathrm{L}^{-1}\right)$, but could reach high levels in agricultural runoff or from contamination by human or animal waste. The nitrate levels in the districts of Baran, Rajasthan are generally less than $45 \mathrm{mg} \mathrm{L}^{-1}$ except for $6 \%$ of the samples of the water, a though the groundwater levels are often higher. The observed fluoride value range in the tube well water was 0.6 to $5.8 \mathrm{mg} \mathrm{L}^{-1}$ and 
0.33 to $9.89 \mathrm{mg} \mathrm{L}^{-1}$ in the hand pump (Table 1). A high fluoride concentration contamination $\left(>1.5 \mathrm{mg} \mathrm{L}^{-1}\right)$ exists in $49 \%$ of the samples. High fluoride ( $>1.5 \mathrm{mg} \mathrm{L}^{-1}$ ) may cause various types of fluorosis.

An abnormal level of fluoride in water is common in fractured hard rock zones with pegmatite veins (Ozha, 2012). The veins are composed of minerals such as topaz, fluorite, fluor-apatite, villuamite, cryolite, and fluoride replaceable hydroxyl ions in ferro-magnesium silicates. Fluoride ions from these minerals leach into the groundwater and contribute to high fluoride concentrations (Singh et al., 2011). Occasionally, the mica group of minerals such as muscovite and biotite, also contribute to water's fluoride content. Again, it is evident from the chemical analysis of the groundwater samples that the $\mathrm{pH}$ value of the groundwater in the affected area varies from 7.3 to 8.1 , indicating a saline condition in nature, which favors the solubility of fluorine-bearing minerals. In an acidic medium (acidic $\mathrm{pH}$ ), fluoride is adsorbed in clay; however, in a saline medium, it is desorbed, thus a saline $\mathrm{pH}$ is more favorable for fluoride dissolution activity. Fluoride has a unique chemical behavior towards most of the anions and can be easily replaced even under normal temperature and pressure conditions. Generally, a high concentration of sodium will increase the solubility of fluoride-bearing minerals in water. This is the reason for the higher levels of fluoride in the groundwater of the area studied. Under the prevailing semi-arid climatic conditions, i.e., during the weathering of granite gneissic rocks, fluorine is released from apatite and biotite to the circulating alkaline groundwater (Karanath, 1987).

Richards (1954) categorized the groundwater on the basis of SAR values ( $<10$ as excellent; between $10-18$ as good; $18-26$ as fair; and $>26$ as poor quality). The data revealed (Table 1) that the different administrative subdivisions of the district of Baran, Rajasthan, have groundwater with SAR values less than 10.0. It has been also delineated that $13 \%$ of the samples from the region indicated excellent groundwater quality.

The observed RSC values overall ranged between -28.2 to 5.1 meq $\mathrm{L}^{-1}$. A negative RSC indicates that a sodium build up is unlikely, since the sufficient calcium and magnesium are in excess of what could be precipitated as carbonates.

The water quality index was measured by the WQI calculator using $\mathrm{NO}_{3}^{-}$, the $\mathrm{pH}$ and the temperature. The WQI for the sixty groundwater samples ranged from 35.03 to 67.47 , and the water quality rating was close to medium $(70 \%)$ for drinking purposes. The low value of the WQI at various locations may be ascribed to higher values of TDS, $\mathrm{NO}_{3}^{-}, \mathrm{Na}^{+}, \mathrm{Ca}^{2+}+\mathrm{Mg}^{2+}, \mathrm{Cl}^{-}$, and $\mathrm{F}^{-}$in the groundwater. A further $30 \%$ of the water samples were found to be of bad quality, implying that the groundwater should not be directly used for drinking purposes.

The $\mathrm{pH}$ of water is a measurement of the concentration of hydrogen ions $\left(\mathrm{H}^{+}\right)$in a solution. In the hand pump water, the $\mathrm{pH}$ shows a significant positive correlation with $\mathrm{CO}_{3}{ }^{2-}\left(\mathrm{r}=0.606^{* *}\right)$, $\mathrm{RSC}\left(\mathrm{r}=0.350^{* *}\right), \mathrm{F}^{-}\left(\mathrm{r}=0.253^{*}\right)$ and an insignificant negative correlation with $\mathrm{pH}, \mathrm{Na}^{+}, \mathrm{Ca}^{2+}+\mathrm{Mg}^{2+} \mathrm{SAR}$ and $\mathrm{Cl}^{-}$(Table 2). Further, for the tube well water, the $\mathrm{pH}$ shows a significant positive correla- tion with $\mathrm{CO}_{3}{ }^{2-}\left(\mathrm{r}=0.899^{* *}\right), \mathrm{RSC}\left(\mathrm{r}=0.726^{* *}\right), \mathrm{F}^{-}(\mathrm{r}=0.561)$ and an insignificant negative correlation with $\mathrm{Na}^{+}, \mathrm{K}^{+}, \mathrm{Ca}^{2+}+\mathrm{Mg}^{2+} \mathrm{NO}_{3}^{-}$and $\mathrm{HCO}_{3}$ - (Table 3).

The electrical conductivity (EC) of water depends upon the concentration of ions and its nutrient load. The EC is a measure of the capacity of a substance or solution to conduct electricity. It is an excellent indicator of total dissolved solids, which is a measure of salinity that affects the taste of potable water. In the hand pump water, the EC shows a significant positive correlation with the total dissolved solids (TDS) $\left(\mathrm{r}=1.00^{* *}\right), \mathrm{Ca}^{2+}+\mathrm{Mg}^{2+}(\mathrm{r}=0.252 *)$ and an insignificant negative correlation with $\mathrm{F}^{-}, \mathrm{Na}^{+}$, SAR, RSC and $\mathrm{HCO}_{3}^{-}$(Table 2). For the tube well water, the EC shows a significant positive correlation with $\mathrm{NO}_{3}^{-}\left(\mathrm{r}=0.650^{*}\right)$, TDS $\left(\mathrm{r}=1.00^{* *}\right)$ and an insignificant negative correlation with $\mathrm{K}^{+}, \mathrm{Ca}^{2+}+\mathrm{Mg}^{2+}, \mathrm{HCO}_{3}^{-}$and $\mathrm{F}^{-}$(Table 3 ).

There is a significant relationship between the sodium adsorption ratio (SAR) of groundwater and the extent to which the sodium is absorbed by the soils. If the water used for irrigation is high in sodium and low in calcium content, then the exchangeable calcium in the soil may replace the sodium by the base exchange reaction in the water. This can destroy the soil structure owing to the dispersion of the clay particles.

The SAR shows a significant positive correlation with $\mathrm{Na}^{+}$ $\left(\mathrm{r}=0.985^{* *}\right)$ and an insignificant negative correlation with $\mathrm{NO}_{3}^{-}, \mathrm{pH}$, $\mathrm{EC}, \mathrm{Cl}^{-}, \mathrm{Ca}^{2+}, \mathrm{Mg}^{2+}$ and $\mathrm{F}^{-}$in the hand pump water (Table 2). The SAR shows a significant positive correlation with $\mathrm{Na}^{+}\left(\mathrm{r}=0.927^{* *}\right)$, RSC $\left(\mathrm{r}=0.612^{*}\right)$ and a negative insignificant correlation with $\mathrm{F}^{-}, \mathrm{K}^{+}$and $\mathrm{Ca}^{2+}+\mathrm{Mg}^{2+}$ in the tube well water (Table 3).

In addition to the RSC, the excess sum of carbonate and bicarbonate in groundwater over the sum of calcium and magnesium also influences the suitability of groundwater for irrigation. The continued use of high residual sodium carbonate water affects the yields of crops. RSC shows a significant positive correlation with the $\mathrm{pH}$ $\left(\mathrm{r}=0.350^{* *}\right), \mathrm{HCO}_{3}^{-}\left(\mathrm{r}=0.242^{*}\right)$ and an insignificant negative correlation with the $\mathrm{EC}, \mathrm{Cl}^{-}, \mathrm{Ca}^{2+}+\mathrm{Mg}^{2+}, \mathrm{K}^{+}, \mathrm{NO}_{3}^{-}$in the hand pump water (Table 3$)$. In the tube well water the RSC showed a significant positive correlation with $\mathrm{pH}\left(\mathrm{r}=0.726^{* *}\right), \mathrm{SAR}\left(\mathrm{r}=0.612^{* *}\right)$ and an insignificant negative correlation with $\mathrm{NO}_{3}^{-}, \mathrm{Ca}^{2+}+\mathrm{Mg}^{2+}, \mathrm{K}^{+}$and $\mathrm{Cl}^{-}$in the tube well water (Table 3).

\section{CONCLUSIONS}

From the above study it is clear that the quality and distribution of the ground water in different regions of Rajasthan are uneven and cause problems of scarcity and suitability. Further, the above hydro-chemical study reveals that most of the samples have good water quality parameters suitable for drinking, agriculture and industrial purposes due to the good hydro-geological and hydrological system, and the local geology is considered to be positive in the environment, which does not really react with rainwater. A few of the samples have been detected with a dubious irrigation water quality with reference to fluorine and nitrate in particular. 
Tab. 1 Salient physico-chemical parameters of the tube wells, hand pumps in different administrative subdivisions of the district Baran, Rajasthan.

(A) Baran tehsil

\begin{tabular}{|c|c|c|c|c|c|c|c|c|c|c|c|c|c|c|c|}
\hline \multicolumn{16}{|c|}{ Handpump } \\
\hline \multirow{2}{*}{ Locations } & \multirow{2}{*}{ pH } & \multirow{2}{*}{\begin{tabular}{|c|}
$\left(\mathrm{dS} \mathrm{m}^{-1}\right)$ \\
$E C$ \\
\end{tabular}} & \multicolumn{3}{|c|}{$\mathrm{mg} \mathrm{L}^{-1}$} & \multicolumn{8}{|c|}{ meq L-1 } & \multirow{2}{*}{ W.Q.I } & \multirow{2}{*}{$\begin{array}{l}\text { W.Q. } \\
\text { Rating }\end{array}$} \\
\hline & & & $\mathrm{NO}_{3}^{-}$ & $\mathbf{F}$ & TDS & $\mathrm{Cl}^{-}$ & $\mathbf{K}^{+}$ & $\mathrm{CO}_{3}{ }^{2-}$ & $\mathrm{HCO}_{3}^{-}$ & $\mathrm{Na}^{+}$ & $\mathrm{Ca}^{2+}+\mathrm{Mg}^{2+}$ & SAR & RSC & & \\
\hline Dhakadphada & 7.7 & 1.53 & 0.10 & 1.62 & 979 & 11.0 & 0.24 & 0.2 & 3.8 & 11.7 & 9.1 & 5.49 & $\mid-5.1$ & 67.14 & Medium \\
\hline Mandolaward & 7.8 & 1.59 & 17.61 & 0.67 & 1018 & 6.1 & 0.10 & 0.1 & 4.8 & 12.8 & 6.5 & 6.11 & -1.6 & 37.89 & Bad \\
\hline Charighat Road & 7.7 & 1.39 & 10.12 & 0.88 & 890 & 9.7 & 0.00 & 0.1 & 2.4 & 3.3 & 9.0 & 1.57 & -6.5 & 41.75 & $\mathrm{Bad}$ \\
\hline BalajiDham & 7.6 & 0.75 & 0.02 & 2.22 & 480 & 4.5 & 0.05 & 1.0 & 4.3 & 13.8 & 6.5 & 7.67 & -1.2 & 66.95 & Medium \\
\hline Nareda & 7.5 & 0.51 & 0.05 & 2.07 & 326 & 2.3 & 0.00 & 0.1 & 5.3 & 7.6 & 4.9 & 4.86 & 0.5 & 67.2 & Medium \\
\hline Akheda & 7.7 & 0.63 & 0.04 & 4.32 & 403 & 2.4 & 0.01 & 0.6 & 3.6 & 8.0 & 6.0 & 4.62 & -1.8 & 67.18 & Medium \\
\hline Patheda & 7.6 & 0.59 & 6.16 & 1.79 & 378 & 2.7 & 0.03 & 0.1 & 6.8 & 21.6 & 6.2 & 12.29 & 0.7 & 45.95 & $\mathrm{Bad}$ \\
\hline Mandola & 7.8 & 1.15 & 36.16 & 1.67 & 736 & 7.2 & 0.02 & 0.4 & 2.1 & 8.5 & 6.5 & 4.74 & -4.0 & 37.02 & $\mathrm{Bad}$ \\
\hline Gail Pt. Ld. Mandola & 7.9 & 0.71 & 33.40 & 0.81 & 454 & 3.6 & 0.03 & 1.0 & 3.3 & 4.4 & 6.4 & 2.46 & -2.1 & 36.45 & Bad \\
\hline ChapraMandola & 8.0 & 0.74 & 5.82 & 1.61 & 474 & 3.2 & 0.04 & 0.9 & 2.9 & 17.5 & 4.5 & 11.67 & -0.7 & 44.83 & Bad \\
\hline Ganesh Temple & 7.9 & 0.93 & 25.14 & 1.47 & 595 & 4.5 & 0.04 & 0.6 & 5.2 & 18.9 & 5.7 & 11.18 & 0.1 & 36.45 & $\mathrm{Bad}$ \\
\hline Range & $7.5-8.0$ & 0.51-1.59 & $0.02-36.16$ & $0.67-4.32$ & 326-1018 & $2.3-11.0$ & $0.0-0.2$ & $0.1-1.0$ & $2.1-6.8$ & $3.3-21.6$ & $4.5-9.1$ & $1.57-12.29$ & -5.8 & $36.45-67.2$ & \\
\hline Mean & 7.7 & 1.0 & 12.2 & 1.7 & 612.1 & 5.2 & 0.05 & 0.5 & 4.0 & 11.7 & 6.5 & 6.6 & -2.0 & 49.9 & \\
\hline S.D. & 0.14 & 0.42 & 17.71 & 0.11 & 271.53 & 4.60 & 0.14 & 0.28 & 0.99 & 5.10 & 2.40 & 4.02 & 3.68 & 7.07 & \\
\hline \multicolumn{16}{|c|}{ Tubewell } \\
\hline Mandolaward & 7.8 & 1.51 & 19.40 & 1.02 & 966 & 9.3 & 0.11 & 0.3 & 4.0 & 14.8 & 6.6 & 9.26 & -2.3 & 37.18 & $\mathrm{Bad}$ \\
\hline Khajurpuraward & 7.5 & 1.65 & 158.80 & 1.31 & 1056 & 7.9 & 0.06 & 0.0 & 4.4 & 10.4 & 12 & 4.24 & \begin{tabular}{|l|}
-7.6 \\
\end{tabular} & 37.81 & Bad \\
\hline Dhanmandi & 7.4 & 0.45 & 2.86 & 2.02 & 288 & 4.1 & 0.07 & 0.0 & 3.8 & 4.6 & 32 & 1.15 & -28.2 & 51.74 & Medium \\
\hline Eadgha Colony & 7.5 & 0.55 & 0.25 & 1.23 & 352 & 9.2 & 0.21 & 0.2 & 3.2 & 4.2 & 21 & 1.30 & -17.6 & 66.52 & Medium \\
\hline Range & 7.4-7.8 & \begin{tabular}{|l|}
$0.45-1.65$ \\
\end{tabular} & $0.25-158.8$ & 1.02-2.02 & 288-1056 & $4.1-9.3$ & $0.06-0.21$ & $0.0-0.3$ & $3.2-4.4$ & 4.2-14.8 & $5.1-32$ & $1.15-9.26$ & 30.5 & \begin{tabular}{|l|}
$37.18-66.5$ \\
\end{tabular} & \\
\hline Mean & 7.6 & 1.0 & 45.3 & 1.4 & 665.5 & 7.6 & 0.11 & 0.1 & 3.9 & 8.5 & 17.5 & 4.0 & -16.5 & 48.3 & \\
\hline S.D. & 0.21 & 0.68 & 13.54 & 0.15 & 434.16 & 0.07 & 0.07 & 0.07 & 0.57 & 7.50 & 10.18 & 5.63 & 10.82 & 2.12 & \\
\hline
\end{tabular}

(B) Mangrol tehsil

\begin{tabular}{|c|c|c|c|c|c|c|c|c|c|c|c|c|c|c|c|}
\hline \multicolumn{16}{|c|}{ Handpump } \\
\hline \multirow{2}{*}{ Locations } & \multirow{2}{*}{$\mathbf{p H}$} & \multirow{2}{*}{\begin{tabular}{|c|}
$\left(\mathrm{dS} \mathrm{m^{-1 } )}\right.$ \\
$E C$ \\
\end{tabular}} & \multicolumn{3}{|c|}{$\mathrm{mg} \mathrm{L}^{-1}$} & \multicolumn{8}{|c|}{ meq L-1 } & \multirow{2}{*}{ W.Q.I } & \multirow{2}{*}{$\begin{array}{c}\text { W.Q. } \\
\text { Rating }\end{array}$} \\
\hline & & & $\mathrm{NO}_{3}^{-}$ & $\mathbf{F}^{-}$ & TDS & $\mathrm{Cl}^{-}$ & $\mathbf{K}^{+}$ & $\mathrm{CO}_{3}{ }^{2-}$ & $\mathrm{HCO}_{3}^{-}$ & $\mathrm{Na}^{+}$ & $\mathrm{Ca}^{2+}+\mathrm{Mg}^{2+}$ & SAR & RSC & & \\
\hline Samasapur & 7.7 & 0.65 & 0.34 & 3.08 & 416 & 2.9 & 0.03 & 0.1 & 5.0 & 6.7 & 6.0 & 1.86 & -1.0 & 65.57 & Medium \\
\hline Hanuman Kund & 7.8 & 0.75 & 0.10 & 2.08 & 480 & 4.5 & 0.03 & 0.6 & 2.9 & 9.4 & 7.0 & 5.03 & -3.5 & 66.37 & Medium \\
\hline Both & 7.7 & 0.53 & 0.16 & 2.24 & 339 & 4.2 & 0.04 & 0.2 & 5.8 & 11.5 & 5.1 & 7.16 & 0.9 & 66.66 & Medium \\
\hline Chowki & 8.1 & 0.66 & 48.20 & 1.57 & 422 & 2.9 & 0.11 & 0.3 & 4.9 & 4.2 & 4.6 & 2.76 & 0.6 & 35.03 & Bad \\
\hline Canal & 7.9 & 0.64 & 0.21 & 2.17 & 410 & 2.6 & 0.06 & 0.6 & 4.0 & 8.9 & 7.9 & 4.66 & -3.3 & 65.39 & Medium \\
\hline Bamori & 7.7 & 1.30 & 0.01 & 2.38 & 832 & 7.0 & 0.09 & 0.1 & 6.5 & 6.5 & 14.0 & 2.45 & -7.4 & 66.85 & Medium \\
\hline Ethawa Road & 7.8 & 0.96 & 10.74 & 1.35 & 614 & 2.6 & 0.12 & 0.6 & 3.3 & 9.8 & 6.4 & 5.47 & -2.5 & 40.79 & Bad \\
\hline Kishanpura Road & 8.0 & 1.31 & 0.92 & 3.10 & 838 & 1.9 & 0.01 & 0.8 & 3.3 & 4.5 & 4.0 & 3.22 & 0.1 & 58.29 & Medium \\
\hline Rakshpuriya & 8.1 & 0.95 & 1.00 & 3.14 & 608 & 1.9 & 0.01 & 1.1 & 2.6 & 6.1 & 2.5 & 5.46 & 1.2 & 56.85 & Medium \\
\hline Anta & 7.7 & 0.35 & 0.21 & 0.82 & 224 & 7.2 & 0.12 & 0.4 & 2.7 & 7.8 & 7.1 & 4.12 & -4.0 & 66.46 & Medium \\
\hline Range & $7.6-8.1$ & $0.35-1.31$ & $0.01-48.2$ & $0.82-3.14$ & $224-838$ & $1.9-15.3$ & $0.01-0.11$ & $0.1-1.1$ & $2.6-7.8$ & $1.5-11.5$ & $2.5-14$ & $0.87-7.16$ & -5.6 & $35.03-66.85$ & \\
\hline Mean & 7.8 & 0.8 & 11.1 & 2.2 & 513.5 & 4.8 & 0.05 & 0.4 & 4.6 & 6.9 & 6.8 & 3.8 & -2.2 & 56.5 & \\
\hline S.D. & 0.07 & 0.14 & 30.12 & 1.10 & 90.51 & 5.73 & 0.07 & 0.14 & 2.55 & 0.91 & 3.11 & 1.00 & 0.71 & 8.98 & \\
\hline \multicolumn{16}{|c|}{ Tubewell } \\
\hline Nanyapura & 7.7 & 0.90 & 0.26 & 2.40 & 576 & 3.1 & 0.05 & 0.2 & 5.6 & 6.8 & 7.5 & 3.51 & -1.7 & 65.64 & Medium \\
\hline Uksaya & 8.0 & 0.74 & 0.01 & 5.80 & 474 & 3.3 & 0.05 & 0.4 & 3.9 & 6.9 & 4.0 & 4.89 & 0.3 & 64.64 & Medium \\
\hline Rakshpuriya & 8.1 & 1.30 & 0.16 & 2.46 & 832 & 1.9 & 0.02 & 0.8 & 3.9 & 5.0 & 4.4 & 3.59 & 0.3 & 63.7 & Medium \\
\hline Range & 7.7-8.1 & 0.74-1.30 & $0.01-0.26$ & $2.4-5.8$ & $474-832$ & $1.9-3.3$ & 0.02-0.1 & $0.2-0.8$ & 3.9-5.6 & $5.0-6.9$ & $3.9-7.5$ & $3.51-4.89$ & -1.4 & 63.7-65.64 & \\
\hline Mean & 7.9 & 1.0 & 0.1 & 3.6 & 627.3 & 2.8 & 0.04 & 0.5 & 4.5 & 6.2 & 5.1 & 4.0 & -0.6 & 64.7 & \\
\hline S.D. & 0.28 & 0.28 & 0.07 & 0.04 & 181.02 & 0.85 & 0.02 & 0.42 & 1.20 & 1.24 & 2.19 & 0.06 & 1.41 & 1.37 & \\
\hline
\end{tabular}




\section{(C) Shahabad tehsil}

\begin{tabular}{|c|c|c|c|c|c|c|c|c|c|c|c|c|c|c|c|}
\hline \multicolumn{16}{|c|}{ Handpump } \\
\hline \multirow{2}{*}{ Locations } & \multirow{2}{*}{ pH } & \multirow{2}{*}{\begin{tabular}{|c|}
$\left.\left(d S^{-1}\right)^{-1}\right)$ \\
$E C$ \\
\end{tabular}} & \multicolumn{3}{|c|}{$\mathrm{mg} \mathrm{L}^{-1}$} & \multicolumn{8}{|c|}{ meq L-1 } & \multirow{2}{*}{ W.Q.I } & \multirow{2}{*}{$\begin{array}{c}\text { W.Q. } \\
\text { Rating }\end{array}$} \\
\hline & & & $\mathrm{NO}_{3}^{-}$ & $\mathbf{F}^{-}$ & TDS & $\mathrm{Cl}^{-}$ & $\mathbf{K}^{+}$ & $\mathrm{CO}_{3}{ }^{2-}$ & $\mathrm{HCO}_{3}^{-}$ & $\mathrm{Na}^{+}$ & $\mathrm{Ca}^{2+}+\mathrm{Mg}^{2+}$ & SAR & RSC & & \\
\hline Deori & 7.7 & 0.33 & 0.02 & 1.08 & 211 & 2.7 & 0.05 & 0.1 & 4.1 & 34.5 & 5.0 & 21.82 & -0.8 & 67.16 & Medium \\
\hline Bhoyal & 7.6 & 0.53 & 0.03 & 0.53 & 339 & 3.0 & 0.09 & 0.0 & 5.3 & 42.7 & 5.3 & 26.22 & 0.0 & 67.53 & Medium \\
\hline Bhoyal, Deori & 7.7 & 0.45 & 0.02 & 0.59 & 288 & 2.6 & 0.07 & 0.3 & 3.2 & 12.1 & 5.3 & 7.39 & -1.8 & 67.16 & Medium \\
\hline Guwahadi & 7.6 & 0.49 & 0.01 & 0.72 & 314 & 2.9 & 0.07 & 0.0 & 5.5 & 16.4 & 5.5 & 9.86 & 0.0 & 67.49 & Medium \\
\hline Budanonera & 7.4 & 1.31 & 0.04 & 0.59 & 838 & 6.9 & 0.28 & 0.2 & 5.8 & 28.8 & 9.4 & 13.25 & -3.4 & 67.55 & Medium \\
\hline Tilgawa & 7.7 & 0.79 & 210.60 & 0.51 & 506 & 5.3 & 0.70 & 0.4 & 3.0 & 11.0 & 5.9 & 6.40 & -2.5 & 37.49 & Bad \\
\hline Tilgawa, Shahabad & 7.9 & 0.90 & 0.10 & 9.89 & 576 & 5.6 & 0.04 & 1.0 & 3.5 & 4.6 & 4.7 & 3.00 & -0.2 & 65.8 & Medium \\
\hline Vamangawa & 7.5 & 0.45 & 0.18 & 7.46 & 288 & 4.9 & 0.04 & 0.1 & 5.9 & 7.7 & 4.6 & 4.79 & 1.4 & 67.16 & Medium \\
\hline Vamangawa & 7.9 & 1.11 & 7.10 & 5.40 & 710 & 7.0 & 0.09 & 0.3 & 4.5 & 9.4 & 5.0 & 5.92 & -0.2 & 43.81 & Bad \\
\hline SamaliKaRastha & 7.6 & 0.52 & 0.77 & 1.09 & 333 & 2.5 & 0.10 & 0.0 & 8.3 & 4.0 & 3.2 & 3.16 & 5.1 & 61.8 & Medium \\
\hline BhoyalBathi & 7.6 & 0.55 & 1.95 & 4.46 & 352 & 3.3 & 0.07 & 0.1 & 5.4 & 11.7 & 8.1 & 5.81 & -2.6 & 54.07 & Medium \\
\hline Range & 7.4-7.9 & 0.33-1.31 & $0.01-210.6$ & $0.51-9.89$ & $211-838$ & $2.5-7.0$ & $0.04-0.70$ & $0-1$ & $3.0-8.3$ & $4.0-42.7$ & $3.2-9.4$ & $3-26.22$ & -1.7 & $37.49-67.55$ & \\
\hline Mean & 7.7 & 0.7 & 20.1 & 2.9 & 432.3 & 4.2 & 0.5 & 0.2 & 5.0 & 16.6 & 5.7 & 9.8 & -0.8 & 60.6 & \\
\hline S.D. & 0.07 & 0.16 & 1.37 & 2.39 & 99.70 & 0.42 & 0.02 & 0.00 & 0.92 & 16.12 & 2.19 & 11.32 & 1.27 & 9.26 & \\
\hline \multicolumn{16}{|c|}{ Tubewell } \\
\hline Gattakhera & 7.7 & 0.39 & 0.01 & 0.64 & 250 & 2.4 & 0.05 & 0.4 & 3.5 & 12.4 & 5.7 & 7.29 & -1.8 & 66.85 & Medium \\
\hline Ranipura & 7.6 & 0.56 & 0.06 & 0.56 & 358 & 2.8 & 0.02 & 0.0 & 7.3 & 10.7 & 6.2 & 6.10 & 1.1 & 67.24 & Medium \\
\hline Motohaara & 8.0 & 0.35 & 0.96 & 2.73 & 224 & 2.9 & 0.09 & 0.6 & 4.4 & 4.7 & 4.2 & 3.22 & 0.8 & 57.94 & Medium \\
\hline Range & $7.6-8.0$ & $0.35-0.56$ & $0.01-0.96$ & $0.56-2.73$ & $224-358$ & $2.4-2.9$ & $0.02-0.09$ & $0-0.6$ & 3.5-7.3 & $4.7-12.4$ & $4.1-6.2$ & $3.22-7.29$ & -0.7 & $57.94-67.24$ & \\
\hline Mean & 7.8 & 0.4 & 0.3 & 1.3 & 277.3 & 2.7 & 0.1 & 0.3 & 5.1 & 9.3 & 5.3 & 5.5 & -0.4 & 64.0 & \\
\hline S.D. & 0.21 & 0.03 & 0.67 & 1.48 & 18.38 & 0.35 & 0.03 & 0.14 & 0.64 & 5.47 & 1.06 & 2.88 & 1.84 & 6.30 & \\
\hline
\end{tabular}

(D) Shahabad tehsil - SaheriyaBasti

\begin{tabular}{|c|c|c|c|c|c|c|c|c|c|c|c|c|c|c|c|}
\hline \multicolumn{16}{|c|}{ Handpump } \\
\hline \multirow{2}{*}{ Locations } & \multirow{2}{*}{ pH } & \multirow{2}{*}{$\frac{\left(\mathrm{dS} \mathrm{m}^{-1}\right)}{\mathrm{EC}}$} & \multicolumn{3}{|c|}{$\mathrm{mg} \mathrm{L}^{-1}$} & \multicolumn{8}{|c|}{ meq L-1 } & \multirow{2}{*}{ W.Q.I } & \multirow{2}{*}{$\begin{array}{l}\text { W.Q. } \\
\text { Rating }\end{array}$} \\
\hline & & & $\mathrm{NO}_{3}^{-}$ & $\mathbf{F}-$ & TDS & $\mathrm{Cl}^{-}$ & $\mathbf{K}^{+}$ & $\mathrm{CO}_{3}{ }^{2-}$ & $\mathrm{HCO}_{3}^{-}$ & $\mathrm{Na}^{+}$ & $\mathrm{Ca}^{2+}+\mathrm{Mg}^{2+}$ & SAR & RSC & & \\
\hline BhilkeraMaal & 7.5 & 0.37 & 0.84 & 1.35 & 237 & 2.2 & 0.03 & 0.1 & 5.7 & 10.4 & 5.4 & 6.33 & 0.4 & 61.31 & Medium \\
\hline Bhilkera & 7.5 & 1.13 & 17.48 & 1.00 & 723 & 7.0 & 0.30 & 0.0 & 6.9 & 5.4 & 5.5 & 3.26 & 1.4 & 38.87 & Bad \\
\hline Goverdhanpura & 7.4 & 0.60 & 0.75 & 0.61 & 384 & 5.0 & 0.00 & 0.0 & 6.5 & 35.0 & 8.1 & 17.42 & -1.6 & 62.26 & Medium \\
\hline Ghogra & 7.3 & 0.35 & 0.78 & 1.75 & 224 & 27.0 & 0.02 & 0.1 & 2.0 & 10.2 & 9.5 & 6.35 & -7.4 & 61.93 & Medium \\
\hline Deori & 7.4 & 0.46 & 2.80 & 1.43 & 294 & 31.0 & 0.09 & 0.1 & 4.8 & 7.3 & 19.2 & 2.35 & -14.3 & 52.12 & Medium \\
\hline Chamrana & 7.5 & 0.83 & 0.01 & 0.81 & 531 & 4.6 & 0.19 & 0.2 & 5.6 & 11.6 & 12.9 & 4.56 & -7.1 & 67.42 & Medium \\
\hline Doobtahlaiya & 7.4 & 0.39 & 1.12 & 0.85 & 250 & 2.9 & 0.01 & 0.2 & 6.9 & 9.3 & 5.6 & 5.56 & 1.5 & 59.06 & Medium \\
\hline Haripura & 7.7 & 0.61 & 0.05 & 1.22 & 390 & 3.0 & 0.04 & 0.8 & 3.8 & 7.0 & 4.2 & 4.83 & 0.4 & 66.88 & Medium \\
\hline Goyra & 7.5 & 0.57 & 0.04 & 1.16 & 365 & 6.6 & 0.05 & 0.4 & 3.2 & 10.9 & 5.0 & 6.92 & -1.4 & 67.46 & Medium \\
\hline Hadapura & 7.3 & 1.57 & 5.06 & 0.36 & 1005 & 9.0 & 0.02 & 0.0 & 5.7 & 8.5 & 17.5 & 2.88 & -11.8 & 48.27 & Bad \\
\hline Matiyakheri & 7.7 & 0.69 & 0.78 & 4.10 & 442 & 3.5 & 0.01 & 0.4 & 3.7 & 6.9 & 2.3 & 6.40 & 1.8 & 61.27 & Medium \\
\hline DeoriChamrana & 7.6 & 0.43 & 4.48 & 0.82 & 275 & 2.8 & 0.04 & 0.2 & 3.4 & 67.3 & 5.8 & 39.58 & -2.2 & 48.91 & Bad \\
\hline Range & 7.3-7.7 & $0.35-1.57$ & $0.01-17.48$ & $0.36-4.10$ & $224-1005$ & $2.2-31.0$ & $0-0.30$ & $0-0.8$ & $2.0-6.9$ & $5.4-67.3$ & $2.3-19.2$ & $2.35-39.58$ & -12.5 & $38.87-67.46$ & \\
\hline Mean & 7.5 & 0.7 & 2.8 & 1.3 & 426.7 & 8.7 & 0.07 & 0.2 & 4.9 & 15.8 & 8.1 & 8.9 & -3.9 & 58.0 & \\
\hline S.D. & 0.07 & 0.04 & 2.57 & 0.37 & 26.87 & 0.42 & 0.01 & 0.07 & 1.63 & 40.23 & 0.28 & 23.51 & 1.84 & 8.77 & \\
\hline
\end{tabular}


Tab. 2 Correlation matrix between the physicochemical properties of the hand pump water.

\begin{tabular}{|c|c|c|c|c|c|c|c|c|c|c|c|c|}
\hline & $\mathrm{NO}_{3}^{-}$ & $F^{-}$ & $\mathrm{pH}$ & EC & $\mathrm{Na}^{+}$ & $\mathbf{K}^{+}$ & $\mathrm{Ca}^{2+}+\mathrm{Mg}^{2+}$ & $\mathrm{Cl}^{-}$ & $\mathrm{CO}_{3}{ }^{2-}$ & $\mathrm{HCO}_{3}^{-}$ & SAR & RSC \\
\hline $\mathbf{F}^{-}$ & -0.165 & & & & & & & & & & & \\
\hline pH & 0.157 & $0.253^{*}$ & & & & & & & & & & \\
\hline EC & 0.078 & -0.018 & 0.231 & & & & & & & & & \\
\hline $\mathrm{Na}^{+}$ & -0.094 & -0.278 & -0.224 & -0.219 & & & & & & & & \\
\hline $\mathbf{K}^{+}$ & $0.746^{* *}$ & -0.220 & -0.077 & 0.193 & 0.015 & & & & & & & \\
\hline $\mathrm{Ca}^{2+}+\mathrm{Mg}^{2+}$ & -0.035 & -0.228 & -0.470 & $0.252^{*}$ & -0.051 & 0.073 & & & & & & \\
\hline $\mathrm{Cl}^{-}$ & 0.018 & -0.056 & -0.405 & 0.019 & -0.142 & 0.050 & $0.666^{* *}$ & & & & & \\
\hline $\mathrm{CO}_{3}{ }^{2-}$ & 0.045 & $0.287^{*}$ & $0.606^{* *}$ & 0.067 & -0.200 & -0.091 & -0.325 & -0.231 & & & & \\
\hline $\mathrm{HCO}_{3}^{-}$ & -0.118 & -0.066 & -0.352 & -0.049 & 0.008 & -0.012 & 0.143 & -0.121 & -0.575 & & & \\
\hline SAR & -0.092 & -0.241 & -0.151 & -0.275 & $0.985^{* *}$ & -0.018 & -0.171 & -0.192 & -0.142 & -0.041 & & \\
\hline RSC & -0.014 & 0.214 & $0.350^{* *}$ & -0.256 & 0.034 & -0.083 & -0.921 & -0.708 & 0.149 & $0.248^{*}$ & 0.133 & \\
\hline TDS & 0.078 & -0.018 & 0.231 & $1.000^{* *}$ & -0.219 & 0.193 & $0.252^{*}$ & 0.019 & 0.066 & -0.049 & -0.275 & -0.256 \\
\hline
\end{tabular}

Tab. 3 Correlation matrix between the physicochemical properties of the tube well water.

\begin{tabular}{|c|c|c|c|c|c|c|c|c|c|c|c|c|}
\hline & $\mathrm{NO}_{3}^{-}$ & $\mathbf{F}$ & pH & EC & $\mathrm{Na}^{+}$ & $\mathbf{K}^{+}$ & $\mathrm{Ca}^{2+}+\mathrm{Mg}^{2+}$ & $\mathrm{Cl}^{-}$ & $\mathrm{CO}_{3}{ }^{2-}$ & $\mathrm{HCO}_{3}^{-}$ & SAR & RSC \\
\hline $\mathbf{F}$ & -0.190 & & & & & & & & & & & \\
\hline pH & -0.333 & $0.561^{*}$ & & & & & & & & & & \\
\hline EC & $0.650^{*}$ & -0.073 & 0.110 & & & & & & & & & \\
\hline $\mathrm{Na}^{+}$ & 0.289 & -0.458 & -0.101 & 0.397 & & & & & & & & \\
\hline $\mathrm{K}^{+}$ & -0.049 & -0.161 & -0.303 & -0.116 & -0.184 & & & & & & & \\
\hline $\mathrm{Ca}^{2+}+\mathrm{Mg}^{2+}$ & 0.059 & -0.200 & -0.757 & -0.219 & -0.382 & 0.414 & & & & & & \\
\hline $\mathrm{Cl}^{-}$ & 0.457 & -0.319 & -0.442 & 0.460 & 0.267 & $0.754^{* *}$ & 0.343 & & & & & \\
\hline $\mathrm{CO}_{3}{ }^{2-}$ & -0.386 & 0.367 & $0.899^{* *}$ & 0.008 & -0.237 & -0.122 & -0.561 & -0.399 & & & & \\
\hline $\mathrm{HCO}_{3}^{-}$ & -0.017 & -0.197 & -0.099 & -0.038 & 0.206 & -0.498 & -0.294 & -0.320 & -0.370 & & & \\
\hline SAR & 0.042 & -0.240 & 0.254 & 0.329 & $0.927^{* *}$ & -0.259 & -0.623 & 0.077 & 0.081 & 0.186 & & \\
\hline RSC & -0.069 & 0.174 & $0.726^{* *}$ & 0.202 & 0.379 & -0.455 & -0.995 & -0.374 & 0.510 & 0.391 & $0.612^{*}$ & \\
\hline TDS & $0.650^{*}$ & -0.073 & 0.110 & $1.000^{* *}$ & 0.397 & -0.116 & -0.219 & 0.460 & 0.008 & -0.039 & 0.328 & 0.202 \\
\hline
\end{tabular}




\section{REFERENCES}

Aher, H.R. - Zinjad, D.G. - Gunjal, P.S. - Kuchekar, S.R. (2002) Impact of human activities on the quality of water in Pravara river basin and Pravara left bank canal. Chemical Environment Research 11, pp. 101-109.

American Public Health Association (1992) Standard methods of examination of water and water. APH ( $18^{\text {th }}$ ed.) Washington DC, USA.

Baran district profile (2012) An official website of Baran-district, Rajasthan, India. Available at http://www.baran.nic.in (accessed December 19, 2012).

Bandy, J.T. (1984) Water characteristics. Journal of Water Pollution Contamination Federation 56, pp. 544- 548.

Berner, R.A. - Berner, E.K. (1987) The Global Water Cycle. Prentice Hall, N.J, USA.

CGWB- CPCB (2000) Status of Ground Water Quality and Pollution Aspects In NCT-Delhi. National Data Center, CGWB, Faridabad, India.

Choudhury, M. - Rakshit, A. (2012) Chemical aspects of ground water quality in the shallow aquifers in selected districts of eastern Uttar Pradesh. International Journal of Agriculture Environment \& Biotechnology, Vol.5, No. 4, pp. 309-315.

Ciaccia, L. (1972) Water and Water Pollution Handbook. Mercel Dekker, Inc., New York, USA.

Verma, D.K. - Rakshit, A. (2012) Evaluating Effects of Water Withdrawals on Chemical Aspects of Ground Water Quality in Araziline Block of Varanasi District, Uttar Pradesh, India. International Journal of Agriculture Environment \& Biotechnology, Vol. 5, No. 4, pp. 353-360
Datta, P.S. - Tyagi, S.K. (1996) Major ion chemistry of ground water in Delhi area: Chemical weathering processes and ground water flow regime. Journal Geological Society of India, Vol. 47, No. 2, pp. 105-110.

Gleick, P.H. (1993) Water in Crisis: A Guide to the World Fresh Water Resources. New York, Oxford University Press, USA.

Gupta, A. - Mall, R.K. - Singh, R. - Rathore, L.S. - Singh, R.S. (2006) Water resources and climate change: An Indian Perspective. Current Science, Vol. 90, No. 12, pp. 1610-1626.

Mishra P.S. - Rout, P. (2009) Assessment of Water Quality Index in Mahanadi and Atharabanki Rivers and Taldanda Canal in Paradip Area, India. Journal of Human Ecology, Vol. 26, No. 3, pp. 153-161.

Rao, K.L. (1997) India's Water Wealth Its Assessment, Uses and Projections. Orient Long -man, New Delhi, India, pp. 39-70.

Singh, P. - Rani, B. - Maheswari, R.(2011) Fluoride Contamination in Groundwater of Rajasthan and Its Mitigation Strategies. Journal of Pharmaceutical and Biomedical Sciences, Vol. 6, No. 9, pp. 1-12.

Spalding, R.F. - Exner, M.E. (1993) Occurrence of nitrate in ground water-A review. Journal Environment Quality, Vol. 22, pp. 392-402.

WHO (2004) Guidelines for drinking water quality. Vol. I, $3^{\text {rd }}$ ed., World Health Organization, Geneva. 